\title{
Inovasi Pembuatan Teh Herbal dari Jantung Pisang dengan Tambahan Daun Stevia Sebagai Pemanis Alami
}

\author{
(Innovation of Herbal Tea from the Banana Blossom with the Addition Stevia Leaf \\ As Natural Sweetener) \\ Siska Esperanza Sinulingga*, Loraetta Brety Sebayang, Samuel Sihotang \\ Fakultas Farmasi Institut Kesehatan Medistra Lubuk Pakam, Deli Serdang Sumatera Utara \\ *Email korespondensi: siskaesperanzasinulingga@medistra.ac.id
}

(Article History: Received August 27, 2021; Revised Sept 17, 2021; Accepted Sept 26, 2021)

\begin{abstract}
ABSTRAK
Inovasi bahan dasar yang dapat dijadikan teh herbal adalah jantung pisang, karena memiliki metabolit sekunder berupa flavonoid, kumarin dan golongan fenolik. Penelitian ini bertujuan untuk membuat teh herbal jantung pisang dan mengetahui standar mutunya. Pembuatan teh herbal dilakukan dengan variasi suhu pengeringan $50^{\circ} \mathrm{C} ; 90^{\circ} \mathrm{C} ; 110^{\circ} \mathrm{C}$ dan waktu pengeringan $110 ; 130 ; 150$ menit kemudian dilakukan uji standar mutu dan skrining serbuk teh herbal. Hasil uji persyaratan mutu teh herbal: kadar air $(7,1 \% ; 6,8 \% ; 2,3 \%)$, kadar ekstrak dalam air $(5,96 \% ; 8,6 \% ; 50,76 \%)$, kadar abu total $(7,4 \%$; $6,2 \% ; 3,9 \%)$, kadar abu larut air $(4,62 \% ; 7,88 \% ; 10,09 \%)$, kadar abu tidak larut asam $(0,93 \% ; 0,7 \%$; $0,47 \%$ ), kandungan flavonoid total $0,0002543 \mathrm{mg}$ QE/g ekstrak dan cemaran mikroba $3,3 \times 10^{4}$ koloni/ml. Pembuatan teh jantung pisang dengan tambahan pemanis alami stevia memenuhi standar mutu produk teh herbal.
\end{abstract}

Kata kunci: Teh herbal; jantung pisang; daun stevia; variasi suhu

\section{ABSTRACT}

Basic ingredient innovation that can be used as herbal tea is banana blossom, because of its secondary metabolites such flavonoids, coumarins and phenolic groups. This study aims to make banana blossom herbal tea and determine the quality standard. Formulation of herbal tea by varying drying temperature of $50^{\circ} \mathrm{C} ; 90^{\circ} \mathrm{C} ; 110^{\circ} \mathrm{C}$ and drying time $110 ; 130 ; 150$ minutes, the quality standard test and herbal tea powder screening were carried out. Results of herbal tea quality: water content $(7.1 \% ; 6.8 \% ; 2.3 \%)$, extract content in water $(5.96 \% ; 8.6 \% ; 50.76 \%)$, ash content total (7.4\%; $6.2 \%$; $3.9 \%)$ water soluble ash content $(4.62 \% ; 7.88 \% ; 10.09 \%)$ acid insoluble ash content $(0.93 \% ; 0,7 \%, 0.47 \%$, total flavonoid content $0.0002543 \mathrm{mg}$ QE/g extract, microbial contamination $3.3 \times 104$ colonies $/ \mathrm{ml}$. Formulation of banana blossom tea with the addition of natural sweetener stevia meets the quality standards of herbal tea products,

Keywords: Herbal tea; banana blossom; stevia leaf; temperature variation

\section{PENDAHULUAN}

Teh herbal merupakan salah satu produk minuman campuran teh dan tanaman herbal yang memiliki khasiat dalam membantu pengobatan suatu penyakit atau sebagai penyegar. Teh herbal umumnya campuran dari beberapa bahan yang biasa disebut infusi/tisane yang terbuat dari kombinasi daun kering, biji, kayu, buah, bunga dan tanaman lain yang memiliki manfaat (Ravikumar 2014). Teh herbal dapat dikonsumsi sebagai minuman sehat yang praktis tanpa mengganggu rutinitas seharihari dan tetap menjaga kesehatan tubuh yang dibuat diharapkan dapat meningkatkan cita rasa dari tiap bahan yang digunakan tanpa mengurangi khasiatnya. Teh herbal juga memiliki nilai jual yang sangat tinggi dan dipercaya akan kegunaannya (Winarsi 2011; Verma 2014).

Indonesia merupakan salah satu negara produsen pisang di dunia. Berbeda dengan buahnya yang mempunyai rasa manis dan banyak dimakan oleh masyarakat, jantung pisang yang tidak begitu enak sehingga nilai ekonomisnya relatif rendah dan tidak diminati masyarakat. Jantung pisang mengandung zat gizi yang bermanfaat bagi tubuh, yaitu berupa: protein $12,051 \%$, karbohidrat $34,831 \%$ dan lemak total 
13,050\%, mineral, vitamin A, B1 dan C. Selain itu, jantung pisang memberikan efek kenyang yang lebih lama dibandingkan dengan nasi dan berkhasiat untuk melancarkan pencernaan manusia (Dinas Kehutanan Provinsi Jawa Barat 2014; He 2017). Hasil pengujian di dalam jantung pisang kepok terdapat kandungan kimia berupa flavonoid, kumarin dan golongan fenolik lainnya (Rampe 2015).

Stevia merupakan pemanis alami yang berasal dari tanaman Stevia Rebudiana bertoni dan telah digunakan oleh beberapa negara sebagai pemanis alami pengganti gula. Stevia adalah pemanis alami yang tidak mengandung kalori dan dapat digunakan langsung untuk berbagai kebutuhan. Dengan demikian stevia bisa memberikan jalan keluar bagi konsumen yang beralasan tidak ingin atau tidak dapat mengkonsumsi gula pasir/gula tebu, misalnya penderita diabetes yang sedang menjalankan program diet karena tentu saja gula stevia lebih aman dibandingkan pemanis sintetis/buatan (Mariana 2011). Berdasarkan uraian diatas peneliti tertarik membuat teh herbal dari jantung pisang dengan penambahan daun stevia yang dapat dikonsumsi oleh masyarakat sehingga meningkatkan nilai dan manfaat jantung pisang pada masyarakat luas. Penelitian ini bertujuan untuk membuat teh herbal jantung pisang dengan penambahan daun stevia sebagai pemanis alami, dan mengetahui standar mutu serta komponen bioaktifnya.

\section{METODE}

\section{Alat dan Bahan}

Alat yang digunakan dalam penelitian ini adalah autoklaf (Hirayama HG series), Biological safety cabinet (Haier HR 40IIB2), beaker glass (Pyrex), blender, plantina cup, cawan petri, corong, colony counter (Funke Gerber), erlemeyer, gelas ukur (Pyrex), hot plate, inkubator (Memmert IN55), kertas saring, kuvet, labu ukur, micropipette (Socorex Swiss), neraca analitik, oven, penangas air, pipet, pipet volumetrik, penjepit penjepit, spatula, spektrofotometri UV Vis, dan tabung reaksi.
Bahan-bahan yang digunakan untuk pembuatan teh herbal jantung pisang adalah jantung pisang, daun stevia, $\mathrm{AlCl} 3$, asam klorida $(\mathrm{HCl})$, etanol 96\%, $\mathrm{AgNO}_{3}$, kuersetin, kloroform, pereaksi bourchardat, pereaksi Dragendorff, pereaksi Mayer, magnesium (bubuk), Plate Count Agar (PCA), $\mathrm{NaCl}$ fisiologis $0,85 \%$, akuades steril, alkohol $70 \%$.

Metode yang digunakan dalam penelitian ini adalah metode eksperimen, meliputi pengumpulan dan penyiapan bahan tanaman, pembuatan teh herbal, pengujian persyaratan mutu teh, skrining fitokimia dan identifikasi kadar flavonoid (SNI 3836:2013).

\section{Pembuatan teh herbal jantung pisang}

Pembuatan teh herbal dilakukan dengan memisahkan jantung pisang dari bunga dan bonggolnya, dicuci, ditiriskan dan dipotong kurang lebih $( \pm) 1 \mathrm{~cm}$ lalu dikeringkan di lemari pengering hingga kering lalu disimpan dalam wadah plastik yang tertutup rapat. Bahan yang telah dipotong diletakkan di rak dan dibiarkan layu selama 14 sampai 24 jam, kemudian digulung dan dipelintir untuk melepaskan enzim alami (proses oksidasi), lalu diblender. Serbuk bubuk teh herbal jantung pisang diletakkan di tempat dingin dan lembab, kemudian proses fermentasi berlangsung dengan adanya proses oksidasi dan enzim yang berada dalam tumbuhan tersebut. Pembuatan teh herbal dilakukan dengan variasi suhu pengeringan $50^{\circ} \mathrm{C}, 90^{\circ} \mathrm{C}$ dan $110^{\circ} \mathrm{C}$ dan waktu pengeringan berturut-turut $(110,130$, dan 150 menit).

2. Pembuatan ekstrak etanol jantung pisang Sebanyak 2000 gram serbuk simplisia jantung pisang dimasukkan ke dalam bejana tertutup, ditambahkan 7,5 liter etanol 96\% lalu bejana ditutup dan dibiarkan selama 5 hari terlindung dari cahaya sambil sering diaduk. Kemudian disaring dan ampas dibilas kembali dengan etanol 96\% hingga diperoleh 100 bagian. Maserat ditampung pada botol gelap, dibiarkan di tempat sejuk dan terlindung dari cahaya matahari selama 
2 hari kemudian disaring. Kemudian ekstrak dipisahkan dari pelarutnya menggunakan rotary evaporator, lalu ekstrak dipekatkan kembali dengan menggunakan penangas air.

\section{Skrining fitokimia}

Skrining fitokimia dilakukan untuk mengetahui golongan senyawa flavonoid, alkaloid, saponin dan tanin mengikuti prosedur (Ditjen POM 1995).

\section{Uji persyaratan teh herbal}

Uji persyaratan mutu teh herbal berdasarkan SNI 3836;2013 meliputi uji: keadaan air seduhan, kadar air, kadar ekstrak dalam air, kadar abu, kadar abu larut dalam air, kadar abu yang tidak larut dalam air.

\section{HASIL DAN PEMBAHASAN}

1. Hasil Skrining Fitokimia

Skrining fitokimia dilakukan untuk mendapatkan informasi golongan senyawa metabolit sekunder yang terkandung dalam jantung pisang. Hasil skrining fitokimia serbuk simplisia dan ekstrak jantung pisang dapat dilihat pada Tabel 1.

Tabel 1. Hasil skrining fitokimia serbuk simplisia dan ekstrak jantung pisang

Keterangan:

\begin{tabular}{llc}
\hline No & Skrining & Hasil \\
\hline 1. & Alkaloid & + \\
2. & Flavanoid & + \\
3. & Tanin & + \\
4 & Saponin & + \\
\hline
\end{tabular}

$+=$ mengandung golongan senyawa

- = tidak mengandung golongan senyawa

Hasil skrining menyatakan bahwa terdapat kandungan alkaloid, flavanoid, tanin, dan saponin. Berdasarkan hasil pengujian oleh Rampe (2015), di dalam jantung pisang kapok terdapat kandungan kimia berupa flavonoid, kumarin dan golongan fenolik lainnya. Flavonoid adalah senyawa fenil yang tersubstitusi derivat benzopyran yang terdiri dari kerangka dasar $\mathrm{C}_{15}\left(\mathrm{C}_{6}-\mathrm{C}_{3}-\mathrm{C}_{6}\right)$. Kuersetin, sebagai flavonoid penting, memiliki berbagai khasiat seperti menurunkan tekanan darah, antihiperlipidemia, anti-hiperglikemia, antioksidan, antivirus, antikanker, antiinflamasi, anti-mikroba, neuroprotektif, dan efek pelindung jantung (Hosseini 2021).

\section{Kadar Total Flavonoid}

Penetapan kadar flavonoid dilakukan menggunakan standar kuersetin sebagai kurva baku pada panjang gelombang maksimal kuersetin. Pemilihan kuersetin sebagai larutan standar dikarenakan kuersetin merupakan senyawa yang paling luas penyebarannya yang terdapat pada tumbuhan. Kuersetin dan glikosidanya berada dalam jumlah sekitar $60 \%-70 \%$ dari flavonoid, dan juga serumpun dengan senyawa flavonoid yang dapat bereaksi dengan $\mathrm{AlCl}_{3}$ membentuk kompleks (Gregory 2011). Kurva kalibrasi baku kuersetin diukur pada konsentrasi $6,8,10,12,14 \mathrm{ppm}$ pada panjang gelombang $448,4 \mathrm{~nm}$. Kurva panjang gelombang kuersetin dapat dilihat pada Gambar 1.

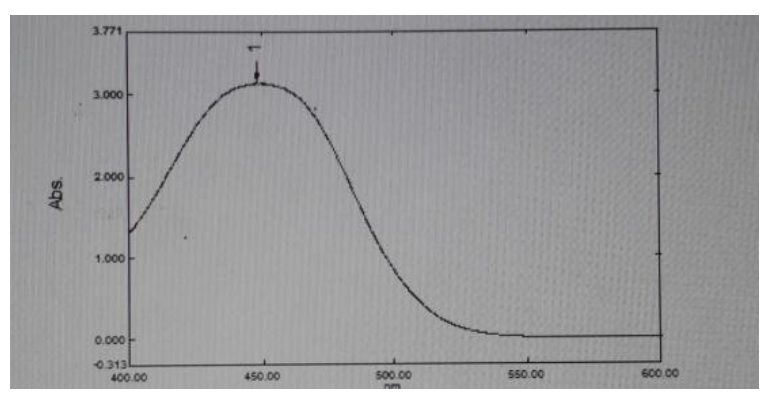

Gambar 1. Kurva panjang gelombang serapan maksimum kuersetin.

Pengukuran absorbansi harus dilaksanakan pada waktu optimum senyawa bereaksi dengan reagen, agar absorbansi yang terukur maksimal. Kurva serapan merupakan kurva menunjukkan hubungan antara absorban dan panjang gelombang. Kurva ini dibuat dengan cara memplotkan nilai absorban pada sumbu y dan konsentrasi pada sumbu x (Ramadhan 2021; Pękal \& Pyrzynska 2014). Pengukuran kurva kalibrasi kuersetin menghasilkan persamaan regresi $\mathrm{y}=0,0616 \mathrm{x}-0,0058$ dengan 
koefisien korelasi $\mathrm{r}^{2}=0,9984$ yang dapat dilihat pada Gambar 2.

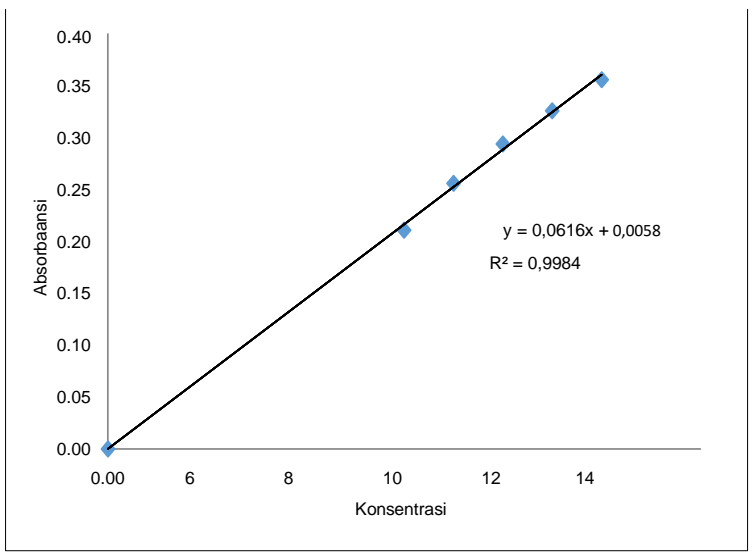

Gambar 2. Kurva korelasi konsentrasi dan absorpsi kuersetin.

Ekstrak jantung pisang memiliki kadar flavanoid total sebanyak 0,0002543\%. Flavonoid merupakan satu golongan senyawa fenol alam yang terbesar dalam tanaman. Hasil yang diperoleh melalui ekstraksi ini masih rendah karena pada pemekatan ekstrak suhunya terlalu tinggi sehingga membuat senyawa flavanoid rusak karena senyawa flavanoid mampu bertahan pada suhu optimal $0{ }^{\circ} \mathrm{C}-65^{\circ} \mathrm{C}$.

3. Hasil analisis standar mutu teh herbal jantung pisang

Uji persyaratan mutu teh herbal berdasarkan SNI 3836;2013 meliputi uji: keadaan air seduhan, kadar air, kadar ekstrak dalam air, kadar abu, kadar abu larut dalam air, kadar abu yang tidak larut dalam air dan cemaran mikroba.

Keadaan air seduhan berdasarkan analisis sensori meliputi parameter warna, aroma, rasa. Menurut SNI 3836:2013 banyaknya panelis yang digunakan untuk rasa, warna dan aroma ialah 4 panelis. Hasil dapat dilihat pada Tabel 2 dan Gambar 3.

Tabel 2. Hasil analisis sensori teh herbal jantung pisang

\begin{tabular}{|c|c|c|c|c|c|}
\hline \multirow[t]{2}{*}{ No } & \multirow{2}{*}{$\begin{array}{c}\text { Kriteria } \\
\text { Uji }\end{array}$} & \multirow[t]{2}{*}{ Persyaratan } & \multicolumn{3}{|c|}{ Variasi formulasi } \\
\hline & & & $\begin{array}{c}\text { Formulasi } \\
1\end{array}$ & $\begin{array}{c}\text { Formulasi } \\
2\end{array}$ & $\begin{array}{c}\text { Formulasi } \\
3\end{array}$ \\
\hline 1 & $\begin{array}{l}\text { Warna air } \\
\text { seduhan }\end{array}$ & Khas produk teh & $\begin{array}{l}\text { Seduhan } \\
\text { berwarna } \\
\text { kecoklatan }\end{array}$ & $\begin{array}{l}\text { Seduhan } \\
\text { berwarna } \\
\text { kecoklatan }\end{array}$ & $\begin{array}{l}\text { Seduhan } \\
\text { berwarna } \\
\text { kecoklatan }\end{array}$ \\
\hline 2 & Bau & Khas produk teh & Aroma teh & Aroma teh & Aroma teh \\
\hline 3 & Rasa & Khas produk teh & Terlalu manis & Amat manis & Rasa manis pas \\
\hline
\end{tabular}

Keterangan:

Formulasi 1: serbuk jantung pisang ( $1 \mathrm{~g})+$ daun stevia $(1 \mathrm{~g})$

Formulasi 2: serbuk jantung pisang $(1,25 \mathrm{~g})+$ daun stevia $(0,75 \mathrm{~g})$

Formulasi 3: serbuk jantung pisang $(1,5 \mathrm{~g})+$ daun stevia $(0,5 \mathrm{~g})$

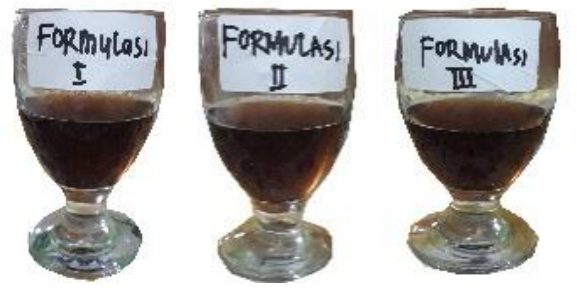

Gambar 3. Hasil seduhan teh herbal jantung pisang.

Hasil pemeriksaan kadar air menunjukkan kadar masing-masing sebesar $7,1 \%, 6,8 \%$ dan $2,3 \%$ yang dapat dilihat pada Gambar 4, terdapat perbedaan kadar air masing-masing suhu dan waktu pengeringan, hal ini menyatakan bahwa semakin tinggi suhu dan waktu pengeringan akan menurunkan nilai kadar air. 


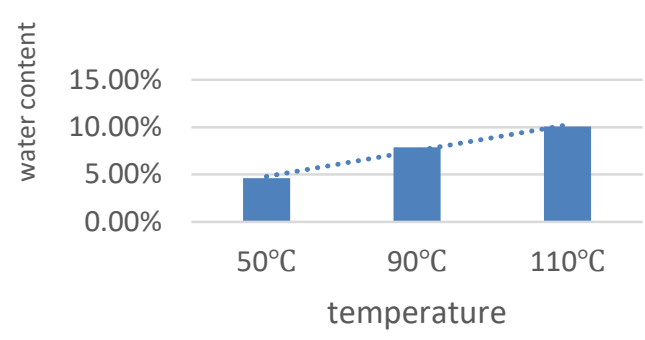

Gambar 4. Faktor suhu dan waktu pengeringan terhadap kadar air.

Kadar air teh herbal jantung pisang dengan penambahan pemanis alami stevia tertinggi pada suhu $50^{\circ} \mathrm{C}$ dengan waktu 110 menit yaitu $9,8 \%$ dan kadar air terendah pada suhu $110^{\circ} \mathrm{C}$ dengan waktu dari 150 menit yaitu $1,4 \%$. Aktivitas kadar air yang rendah dikarenakan tingginya suhu pada saat proses pemanasa berlangsung, aktivitas kadar air yang tinggi disebabkan oleh suhu pemanasan yang rendah. Menurut SNI (2013), persyaratan teh lolos uji dengan kadar air maksimal $8 \%$.

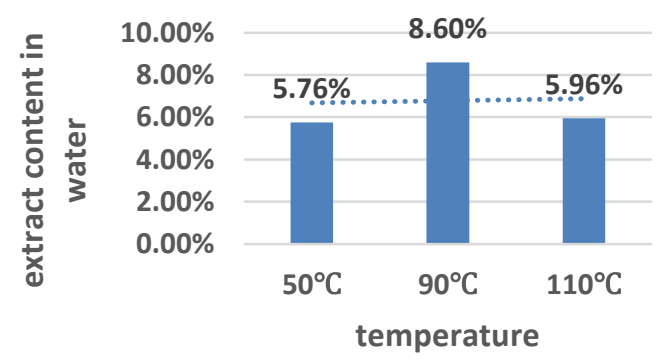

Gambar 5. Kadar ekstrak dalam air.

Berdasarkan Gambar 5 terlihat bahwa terdapat perbedaan kadar ekstrak dalam air pada setiap suhu dan waktu pengeringan, hal ini menyatakan bahwa semakin tinggi suhu dan semakin lama waktu pengeringan maka semakin kecil nilai kandungan ekstrak dalam air. Bimantara (2015), menyatakan bahwa sedikitnya kadar air disebabkan oleh tingginya pemanasan yang dilakukan.

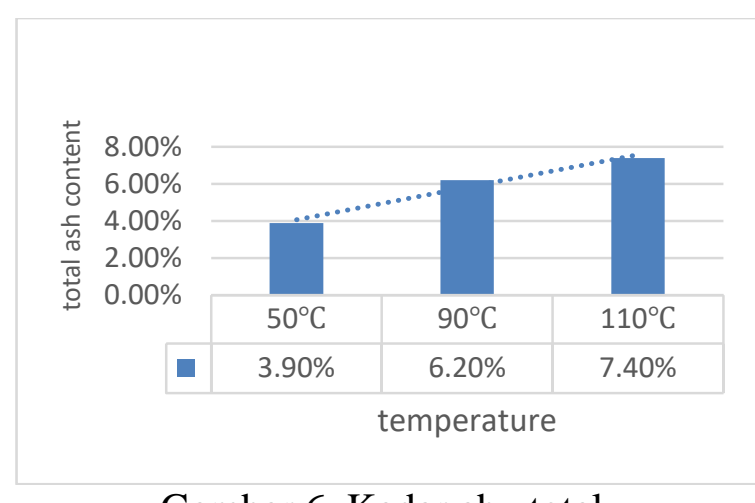

Gambar 6. Kadar abu total.

Hasil pemeriksaan kadar abu total berturut-turut adalah 7,4\%, 6,2\%, 3,9\%. dan menunjukkan bahwa kadar abu total teh tertinggi pada suhu $110^{\circ} \mathrm{C}$ adalah $7,4 \%$ dan terendah pada suhu $50^{\circ} \mathrm{C}$ adalah $3,9 \%$. menunjukkan adanya perbedaan kadar abu total pada setiap suhu dan waktu pengeringan teh herbal jantung pisang dengan penambahan pemanis alami stevia. Lengkey et al. (2014) menyatakan bahwa semakin tinggi kadar air, kandungan bahan keringnya menurun dan komponen lemak dan protein sebagai bahan kering meningkat, sehingga presentase kadar abunya menurun. Kadar abu tergantung pada sampel bahan, proses untuk menjadi abu, waktu dan suhu pada proses pengeringan. Jika waktu dan suhu yang digunakan untuk mengeringkan bahan lebih lama dan tinggi maka kadar abu tinggi begitupun sebaliknya.

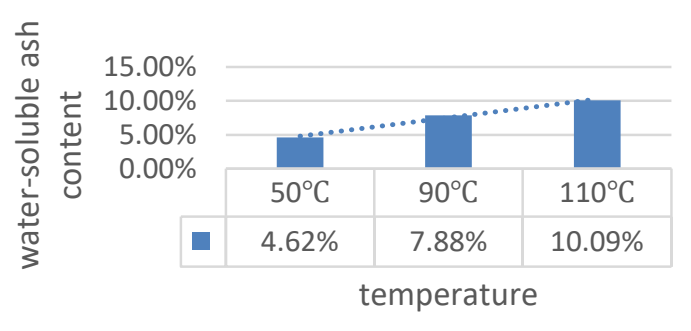

Gambar 7. Kadar abu yang larut dalam air.

Hasil pemeriksaan kadar abu larut dalam air berturut-turut sebesar 4,62\%, 7,88\%, $10,09 \%$ dan menunjukkan kadar abu larut udara tertinggi pada suhu $110^{\circ} \mathrm{C}$ dengan waktu 150 menit yaitu 10,09\% dan kadar abu yang dapat larut air terendah adalah $50^{\circ}$ C selama 110 menit, yaitu 4,62\%. 


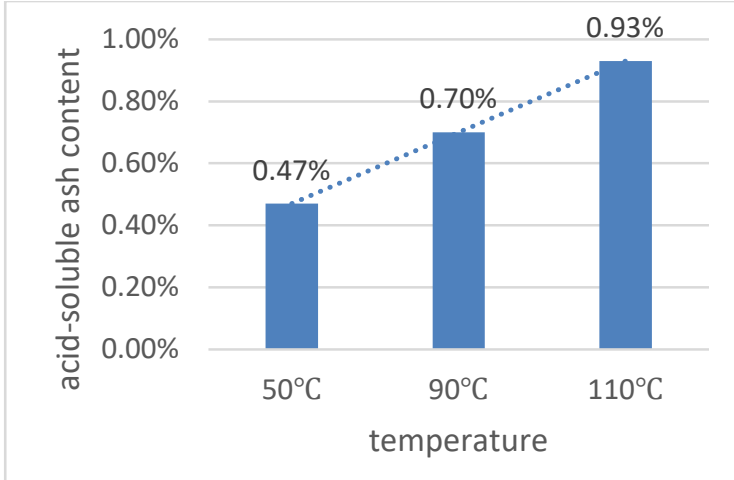

Gambar 8. Kadar abu yang larut dalam asam.
Hasil pemeriksaan menunjukkan kadar abu tidak larut asam tertinggi pada suhu $110^{\circ} \mathrm{C}$ dengan waktu 150 menit yaitu $0,93 \%$. dan kadar abu tidak larut asam terendah pada suhu $50^{\circ} \mathrm{C}$ dengan waktu 110 menit yaitu $0,47 \%$ ini menunjukkan bahwa terdapat perbedaan kadar abu total pada setiap suhu dan waktu pengeringan teh herbal. Jika waktu dan suhu yang digunakan untuk mengeringkan bahan lebih lama dan lebih tinggi maka akan menghasilkan kadar abu yang tinggi, tetapi jika suhu dan waktu yang rendah dan cepat kadar abu yang rendah (Riansyah 2013).
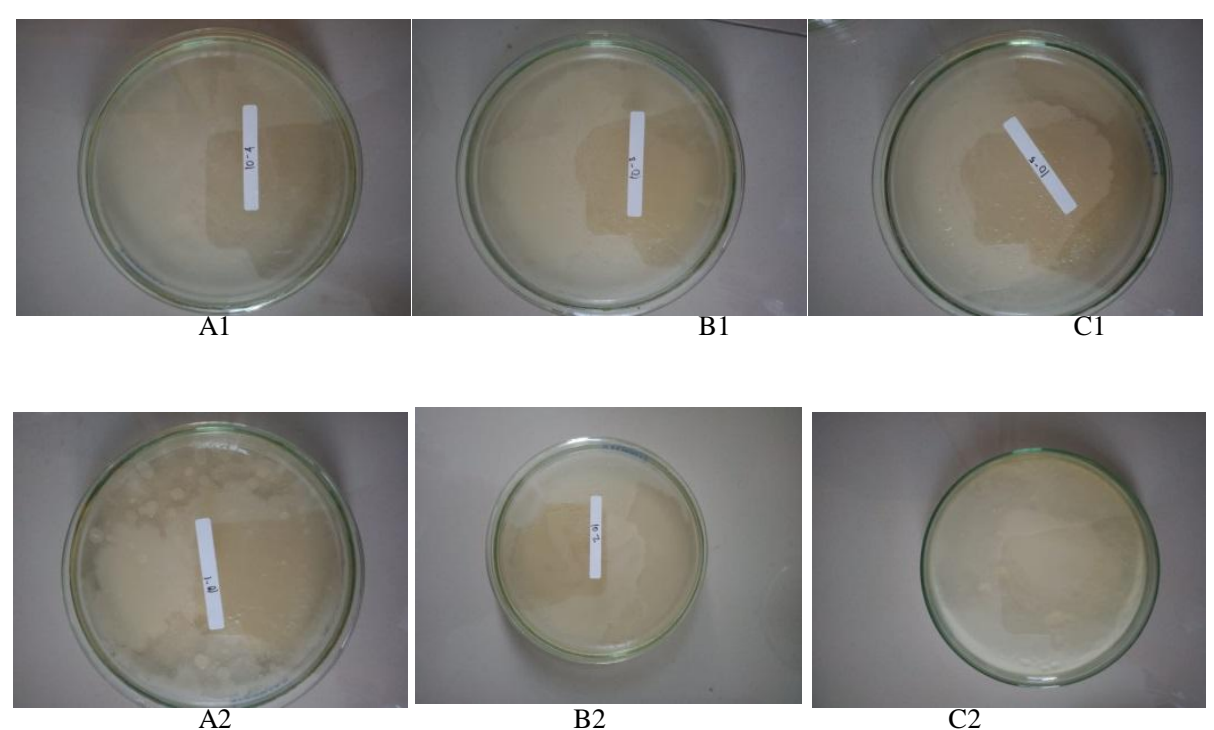

Gambar 9. Hasil uji ALT teh herbal jantung pisang.

Keterangan :

A1 : sampel teh herbal pengenceran $10^{-2}$ (cawan petri 1)

B1 : sampel teh herbal pengenceran $10^{-3}$ (cawan petri 1)

C1 : sampel teh herbal pengenceran $10^{-4}$ (cawan petri 1)

A2 : sampel teh herbal pengenceran $10^{-2}$ (cawan petri 2 )

B2 : sampel teh herbal pengenceran $10^{-3}$ (cawan petri 2)

C2 : sampel teh herbal pengenceran $10^{-4}$ (cawan petri 2)

Persentase hasil Uji ALT :

$$
\begin{gathered}
=\frac{\sum c}{\left\{\left(1 \times n_{1}\right)+\left(0,1 \times n_{2}\right)\right\} \times d}=\frac{394}{1,2 \times 10^{-2}} \\
=328,33 \times 10^{2}=3,3 \times 10^{4}
\end{gathered}
$$

Angka Lempeng Total yang diperoleh dari rata-rata pengulangan sebesar $3,3 \mathrm{x}$ $10^{4} \mathrm{koloni} / \mathrm{ml}$ yang dianalisa memenuhi persyaratan. Perbedaan nilai Angka
Lempeng Total pada produk teh herbal disebabkan oleh sanitasi dan kebersihan pada tahap produksi, perlakuan pemanasan pada tahap pembuatan teh herbal dari 
jantungpisang dan penyimpanan. Perlakuan pemanasan dilakukan untuk memusnakan mikroorganisme, akan tetapi sebagian organisme dapat hidup dengan membentuk endospora oleh sebab itu, terdapat perbedaan jumlah mikroba yang hidup pada tiap produk teh herbal dari jantung pisang (Sa'diyah 2020).

\section{KESIMPULAN}

Pembuatan teh herbal jantung pisang dengan tambahan pemanis alami stevia dapat di gunakan sebagai produk teh herbal dan telah memenuhi persyaratan mutu teh herbal. Komposisi proporsi teh herbal jantung pisang dan daun stevia yang paling diminati yaitu formulasi ketiga yang mengandung serbuk jantung pisang sebanyak $1,5 \mathrm{~g}$ dan daun stevia sebanyak 0,5 g.

\section{UCAPAN TERIMA KASIH}

Penulis mengucapkan kepada Kementerian Pendidikan, Kebudayaan, Riset, dan Teknologi, Direktorat Jendral Pendidikan Tinggi atas bantuan biaya pada skema hibah Penelitian Dosen Pemula (PDP); juga ucapan terimakasih kepada Bapak Rektor Institut Kesehatan Medistra Lubuk Pakam atas pemberian izin menggunakan fasilitas laboratorium yang sangat memadai untuk melakukan penelitian ini.

\section{DAFTAR PUSTAKA}

Bimantara F, Supriadi A, Hanggita, S (2015) Modifikasi dan Pengujian Alat Pengasapan Ikan Sistem Kabinet. Jurnal FishtecH, 4(1), 46-56.

Dinas Kehutanan Provinsi Jawa Barat (2014) Jantung Pisang Kaya Serat dan Manfaat.http://dishut.jabarprov.go.id/?m od=detilBerita\&idMenuKiri=\&i

dBerita $=3740$. [Diakses pada 18 Desember 2016].

Ditjen POM (1995) Farmakope Indonesia. Edisi IV. Jakarta: Departemen Kesehatan Republik Indonesia. Halaman 10831084.
Gregory S, Kelly ND (2011) Quercetin. Altern. Med. Rev. 16(2):172-194

Ramadhan H, Rezky DP, Susiani EF (2021) Penetapan Kandungan Total FenolikFlavonoid pada Fraksi Etil Asetat Kulit Batang Kasturi (Mangifera casturi Kosterman). Jurnal farmasi dan ilmu kefarmasian indonesia, 8(1), 58-67.

He X, Li L, Sun J, Li C, Sheng J, Zheng F, Tang Y (2017) Adenylate quantitative method analyzing energy change in postharvest banana (Musa acuminate L.) fruits stored at different temperatures. Scientia Horticulturae, 219, 118-124.

Hosseini A, Razavi BM, Banach M, Hosseinzadeh H (2021) Quercetin and metabolic syndrome: A review. Phytotherapy Research.

Lengkey HAW, Garnida D, Suryaningsih L (2014) The Effect of Length of Soaking in Papain on Meat Water Content, $\mathrm{pH}$ and Tenderness of Culled Layer Hens. $J$. of Animal Science. Sofia, 51(1/2), 159161.

Mariana, Raini, Isnawati A (2011) Kajian Khasiat dan Keamanan Stevia sebagai Pemanis Pengganti Gula. Jurnal Media Litbang Kesehatan. 21 (4).

Pękal A, Pyrzynska K (2014) Evaluation of Aluminium Complexation Reaction for Flavonoid Content Assay. Food Analytical Methods; 7; 1776-1782.

Rampe MJ, Tombuku JL (2015) Pengujian Fitokimia dan Toksisitas Ekstrak Etanol Jantung Pisang Kepok (Musa paradisiaca LINN.) dengan Metode Brine Shrimp Lethality Test (BSLT). Jurnal Sainsmat, 4 (2), 136-147.

Ravikumar, C (2014) Review on herbal teas. Journal of Pharmaceutical Sciences and Research, 6(5), 236.

Riansyah A, Supriadi A, Nopianti R (2013) Pengaruh perbedaan suhu dan waktu pengeringan terhadap karakteristik ikan asin sepat siam (Trichogaster pectoralis) dengan menggunakan oven. Jurnal Fishtech, 2(1), 53-68.

Sa'diyah L, Lestari KAP (2020) Pengaruh Lama Pemanasan Terhadap Nilai ALT 
Bakteri Teh Kombucha. Journal of Pharmacy and Science. 5 (1); 21-24.

SNI 3836:2013 (2013) Standar Mutu Teh Kering. Dewan Standarisasi Nasional. Jakarta.

Verma A, Alpana S (2014) Optimization and Quality assessment of Low-Calorie Herbal Tea Sweetened with Stevia (Stevia rebaudiana). Journal of Medical Research and Development. 3(2):134137.

Winarsi, Hery (2011) Antioksidan Alami dan Radikal Bebas. Yogyakarta: Kanisius. 